\title{
Epidemiological Studies of Downy Mildew of Onion
}

\author{
Ankita $^{1 *}$, Sunita Chandel ${ }^{1}$, Rajender Sharma ${ }^{2}$ and Vijay Kamal Meena ${ }^{3}$ \\ ${ }^{1}$ Department of Plant pathology, College of Horticulture, Dr. YS Parmar University of \\ Horticulture \& Forestry, Nauni, 173230 Solan, India \\ ${ }^{2}$ Department of Seed Science and Technology, College of Horticulture, Dr. YS Parmar \\ University of Horticulture \& Forestry, Nauni, 173230 Solan, India \\ ${ }^{3}$ Division of Genetics, ICAR-Indian Agricultural Research Institute, New Delhi, India
}

*Corresponding author

\section{A B S T R A C T}

Ke y w o r d s
$\begin{aligned} & \text { Epidemiology, } \\ & \text { Onion, Downy } \\ & \text { mildew, } \\ & \text { Temperature, } \\ & \text { Relative humidity }\end{aligned}$
Article Info
$\begin{aligned} & \text { Accepted: } \\ & \text { 05 April } 2020 \\ & \text { Available Online: } \\ & \text { 10 May } 2020\end{aligned}$

\section{Introduction}

Onion is an important vegetable crop grown in sub-tropical and dry temperate zones of India and all through the world including temperate as well as in tropics (Ross, 2001). It is grown as bulb crop and as seed crop. It contains high level of vitamin $\mathrm{C}$, phosphorus, calcium and sulphur, making it a very valuable vegetable.
It has a very important place in everyone's kitchen. Major constraints in growing onion are diseases, pest, frost injury and others. Among all such factors, downy mildew is one of the threats affecting the yield level as well as quality.

Downy mildew is very notorious disease known to affect every variety bred till far 
(Gianessi and Reigner, 2005). Yield losses up to the levels of 75.11 per cent accomplished because of downy mildew as per Jayakumar $e t$ al., 2008. These losses, basically result from serious infections in onion bulbs, causing early defoliation, diminished bulb sizes, moreover, poor storage quality of bulbs (Surviliene et al., 2008). Being a staple to every Indian's cuisine, the impact of downy mildew is threatening, so an attempt was made to study the role of various factors on infection and development of the disease under in vitro as well as in vivo.

The disease is known to appear at all stages of growth and characterized by white slightly sunken circular or elliptical lesion. Such lesions were found on the single side of the stalk and mostly on the older leaves. With the passage of time these lesions were covered with the grey downy masses that turned purplish after heavy rain. After the infection leaf colour changes from light green to yellow followed by necrosis of particular area. Downy growth associated with infected tissues usually consists of sporangia and the sporangiophores having characteristic branching. Infection at younger stage has caused systemic infection by inducing stunting, defoliation, declining and death of plant tissues. Affected leaves were light green and showed tip die-back in the form of necrosis and curling. Pattern of yellowing in the field was seen extended out in the direction of prevailing wind. In case of severe downy mildew infestation lesions become necrotic followed by girdling and collapsing of that portion of leaf that leads to hanging of leaf stalk from the point of necrosis. Few bottleneck bulbs were also seen due to severe infection of aerial portions of the plant.

\section{Materials and Methods}

The experiment was conducted at Pandah Research Farm of Department of Seed Science and Technology of Dr. Yashwant Singh Parmar University of Horticulture \& Forestry, Nauni, Solan, HP. Survey was done by throwing a quadrat of one square metre in a field randomly at five places and number of healthy and diseased plants was counted and disease incidence was recorded at seven days interval starting from the date of sowing, by using 0 - 9 scale (Mohibullah, 1991) as described below (Table.A). The PDI (per cent disease index) was calculated by using the formula given by Mc Kinney (1923).

$$
\text { PDI }(\%)=\frac{\text { Sum of all disease ratings }}{\text { Total no. of ratings } \mathrm{x} \text { Maximum disease grade }} \times 100
$$

Table.A

\begin{tabular}{|l|l|l|}
\hline Key Scale & Description & Intensity (\%) \\
\hline $\mathbf{1 .}$ & No symptom of disease. & 0 \\
\hline $\mathbf{2 .}$ & Only few leaves affected. & 1 \\
\hline $\mathbf{3 .}$ & Less than half of the plant affected. & 5 \\
\hline $\mathbf{4 .}$ & Most of the plants affected but the attack restricted mostly & 10 \\
\hline & to one leaf per plant. & \\
\hline $\mathbf{5 .}$ & All the plant affected and attack restricted to one or two leaves. & 20 \\
\hline $\mathbf{6 .}$ & Three to four leaves of almost every plant affected and the & 50 \\
\hline & crops look fair green. & \\
\hline $\mathbf{7 .}$ & Three to four leaves of almost every plant affected and the \\
\hline $\mathbf{8 .}$ & crops show blighted appearance. & 75 \\
\hline & All the leaves of all plants severely attacked; greenness & \\
\hline 9. & restricted to the central shoot only. & 90 \\
\hline & Foliage completely blighted due to downy mildew, purple & 100 \\
\hline
\end{tabular}


The pathogen was identified by following the keys given by Murphy and Mckay (1926) by bringing infected leaves with characteristics symptoms.

Detached leaf method (Song et al., 1998) was used for conducting the pathogenicity test where fresh healthy leaves of onion were surface sterilized and air dried, then placed in plastic trays lined with thin layer of cotton and blotting paper completely saturated with distilled water. Inoculation was done with the spore suspension (4 x 104 sporangia per ml). The set-up was incubated for $14^{\circ} \mathrm{C}$ (4 days) followed by $18^{\circ} \mathrm{C}$ for 8 days in $\mathrm{BOD}$ incubator.

Effect of different temperature $\left({ }^{\circ} \mathrm{C}\right)$ and relative humidity $(\%)$ regimes on sporangial germination and germ tube formation under in vitro

The optimum temperature and relative humidity for sporangial germination and germ tube formation of Peronospora destructor, sporangia were harvested and adjusted to $4 \mathrm{x}$ 104 sporangia per ml. Sporangial suspension was placed in cavity slides in Petriplates lined by cotton. These Petriplates were incubated in BOD incubator at $5^{\circ} \mathrm{C}, 10^{\circ} \mathrm{C}, 15^{\circ} \mathrm{C}, 20^{\circ} \mathrm{C}$, $25^{\circ} \mathrm{C}$ and $30^{\circ} \mathrm{C}$.

Three replications were maintained for each temperature and design followed was Completely Randomised Design (CRD). Germination of sporangia were recorded at an interval of 12 hours, 24 hours and 36 hours by counting the empty sporangia and per cent germination was calculated by using the following formula:

$$
\text { Spore germination }(\%)=\frac{\text { Number of sporangia geminated }}{\text { Total number of sporangia }} \times 100
$$

After 12, 24, 36 hours of incubation, spores were also examined for measuring germ tube length.

For different relative humidity levels (\%) at $15^{\circ} \mathrm{C}$ (best temperature for sporangial germination), sporangia were harvested and made into a solution of required concentration in a similar way as in 2.3.1. After that Petriplates containing cavity slides were then incubated at $15^{\circ} \mathrm{C}$ at different humidity levels viz. $0,56.8,75.6,82.9,95.198 .5$ and 100 per cent by using the method given by Stevens (1960). Spore germination and germination percentage was calculated by using the formula as discussed above.

\section{Progression of disease under natural epiphytotic conditions}

Disease infection is affected by prevalence of different meteorological factors which are mainly temperature, relative humidity and rainfall. Therefore, in order to study their effect on the progress of downy mildew of onion under natural epiphytotic conditions, data on disease severity were recorded at 4 days interval with effect from the last week of February 2018 to the second week of May, 2018. The data on the weather parameters were obtained from the Meteorological Observatory, Department of Environment Science, Dr. Y. S. Parmar University of Horticulture and Forestry, Nauni, Solan (H.P.) to find out their effect on disease initiation and subsequent spread.

Further, correlation and regression coefficients were also calculated by following the procedures as described by Gomez and Gomez (1984) and regression lines were developed. The per cent disease index of each interval was also calculated. The time of appearance of disease in days and disease severity at each interval was also calculated. 


\section{Results and Discussion}

\section{Disease survey}

Systematic surveys of onion growing areas in Solan district of Himachal Pradesh during the crop season 2017 - 2018, (Table 1) has revealed that the disease was prevalent as very low, moderate and severe form in these onion growing areas.

From the data (Table 1), it is also evident that the disease was widespread in all the areas surveyed. However, disease incidence was highest (39.24 \%) in Pandah and lowest (10.24 $\%$ ) in Dharampur due to the prevailing of dew for longer period in winter season. The intensity of the disease was reported to be quite high up to 100 per cent in different parts of world (Kennedy, 1989).

It has got global occurrence and becomes more relevant in temperate regions (Domingues and Tofoli, 2009). The distribution of this pathogen is global (Brewster, 2001) and affects crop yields by more than 60\% (Surviliene et al., 2008).

\section{Causal organism}

The pathogen was identified as Peronospora destructor (Berk.) Casp. ex Berk. on the basis of microscopic study. The mycelium was aseptate hyaline and dichotomously branched measuring 3.6 to $6.9 \mu \mathrm{m}$ in width, whereas size of sporangiophores varies greatly. The size of sporangia ranged from 50.4 to $65.8 \times$ 24.6-25.2 $\mu \mathrm{m}$ and colour of sporangia was hyaline, having pyriform to fusiform shape.

On the basis of explained morphological characters the pathogen was identified above findings were well supported by the work of Langston and Sumner (2000) and Göker et al., (2007).

\section{Pathogenicity test}

Pathogenicity test, was conducted on 25 days old plants of cultivars "Palam Lohit" by spraying sporangial suspension of $4 \times 104$ sporangia / $\mathrm{ml}$ and Koch's postulates were proved. The leaves inoculated with sporangial suspension supported the growth of sporangia, 8 days after inoculation (Fig.1), yielding faster and maximum $(60 \%)$ of sporulation at higher humidity (95-96 \%) at $10-15{ }^{\circ} \mathrm{C}$.

Such observation has also been reported by Develash and Sugha, 1997. Latency period up to the development of new sporulation lasts from 9 to 16 days (Schwartz and Mohan, 2008).

\section{Epidemiological studies}

In vitro effect of different temperature regimes on sporangial germination and germ tube length production.

Effect of temperature on sporangial germination and germ tube length of Peronospora destructor were recorded and presented in Table 2. Maximum spores (73.96\%) germinated at $15 \mathrm{oC}$ temperature at 36 hours giving highest germ tube length $(202.98 \mu \mathrm{m})$ suggesting that $15^{\circ} \mathrm{C}$ is best for spore germination and formation of germ tube.

Similar findings were reported by other workers (Kofoet, 1986) using incubation periods of 22 and $48 \mathrm{hr}$ as the optimum germination range of Peronospora tabacina at $15-23^{\circ} \mathrm{C}$. According to Palti (1989) the rate of spore germination is highest at $10{ }^{\circ} \mathrm{C}$ and declines with the rise in temperature which is contrary to our study, as $15^{\circ} \mathrm{C}$ has supported maximum germination of sporangia. The time taken for sporulation by $P$. belbahrii is completed within about 11 hours from the onset of darkness in moisture saturated atmosphere at $18^{\circ} \mathrm{C}$ (Cohen et al., 2016). 
In vitro effect of different relative humidity (\%) levels on sporangial germination and germ tube length production

Study of different levels of relative humidity $(\mathrm{RH})$ on germination and germ tube length of sporangia are given in Table 3 . The results revealed that sporangia germinated only at 95.1, 98.5 and 100 per cent relative humidity by giving germination percentage of 33.12 , 62.35 and 71.40 in increasing order with the increase in the RH levels.

The levels of relative humidity also showed the concurrence in germ tube length formation which was lowest $(78.23 \mu \mathrm{m})$ at 95.1 per cent RH and highest at 100 per cent RH (126.91 $\mu \mathrm{m})$ with a gradual increase in germ tube length as the levels of RH increased.

Hence very high relative humidity above 95.1 per cent to 100 per cent is needed for the sporangial germination at optimum temperature of $15{ }^{\circ} \mathrm{C}$. Leach (1985) has also reported similar results showing that lower relative humidity causes rapid loss of viability of sporangia. Cohen et al., (2013) has also reported that Peronospora belbahrii requires moisture-saturated atmosphere in the dark for sporulation.

Severe mildew outbreaks under semi-arid and rainless conditions is attributed due to favourable early morning temperatures and the limited hours of high humidity (Palti, 1989). Sporangial germination was decreased to almost zero level due to decrease in the relative humidity of 93 per cent and hence no formation of germ tube as reported by Gilles et al., (2004).

Role of meteorological factors on disease epiphytotics under field conditions

The data on severity of the disease was recorded after the establishment of the crop and once the disease appeared in the field, observations were taken at four days intervals commencing from 25th Feb to 15th May, 2018 and are presented in Table 4.

The data on weather parameters and disease development revealed that the disease did not appear during cropping period, 2017 and till mid of February, 2018 but only in the 4th week (25-28 February) the disease initiated with the prevalence of congenial weather conditions such as relatively high average relative humidity of 52.8 per cent accompanied by cumulative rainfall $(3.4 \mathrm{~mm})$, mean maximum $\left(22.12^{\circ} \mathrm{C}\right)$ and minimum $\left(7.6^{\circ} \mathrm{C}\right)$ temperatures.

There was increasing trend in disease level and it assumed serious proportion (70 to $72.76 \%$ ) during the mid-April, 2018 however maximum 72.76 per cent disease index was noticed on first week, 6 - 9 April of observation dates when the mean maximum, minimum temperatures and average relative humidity remained within the range of 25.3 to $27.5^{\circ} \mathrm{C}, 5.8$ to $12.3^{\circ} \mathrm{C}$ and 58 to 68 per cent that leads to prolific sporulation of Peronspora destructor.

The disease however decreased slowly thereafter and reached to $66.65 \%$ up to the harvesting time of the crop due to the decomposed lower leaves and emergence of the new leaves. These results to a greater extent also corroborate the findings of various workers. (Premila and Sophiarani, 2015; Premila, 2013). Viranyi (1975) observed that germination occurred most rapidly (2-3 h) at $10-18^{\circ} \mathrm{C}$ and took somewhat longer $(4 \mathrm{~h})$ at $22^{\circ} \mathrm{C}$ and longest (5-7 h) at $5^{\circ} \mathrm{C}$.

Temperatures of $10-12^{\circ} \mathrm{C}$ are apparently optimal for most stages, $14-18{ }^{\circ} \mathrm{C}$ is still quite favourable, but temperatures above $22{ }^{\circ} \mathrm{C}$, rapidly become unfavourable, especially at lower humidity level. 
Table.1 Severity of onion downy mildew disease at different locations in Solan of Himachal Pradesh during 2017-18

\begin{tabular}{|l|c|c|}
\hline Location (s) & $\begin{array}{c}\text { Disease } \\
\text { incidence }\end{array}$ & $\begin{array}{c}\text { Disease index } \\
\mathbf{( \% )}\end{array}$ \\
\hline Nauni & 30.33 & 21.76 \\
\hline Pandah & 39.24 & 58.65 \\
\hline Khaltoo & 31.25 & 35.86 \\
\hline Maryog & 22.3 & 28.43 \\
\hline Dharampur & 10.24 & 4.78 \\
\hline Kandaghat & 14.3 & 6.76 \\
\hline Oachghat & 18.33 & 21.16 \\
\hline Mean & $\mathbf{2 3 . 7 1}$ & $\mathbf{2 8 . 9 6}$ \\
\hline
\end{tabular}

Table.2 Effect of different temperature regimes on sporangial germination and germ tube length of Peronospora destructor

\begin{tabular}{|c|c|c|c|c|c|c|c|c|}
\hline \multirow{2}{*}{$\begin{array}{l}\text { Temperature } \\
\left({ }^{\circ} \mathbf{C}\right)\end{array}$} & \multicolumn{3}{|c|}{ Sporangial germination $(\%)$} & \multirow[b]{2}{*}{ Mean } & \multicolumn{3}{|c|}{ Germ tube length $(\mu \mathrm{m})$} & \multirow[b]{2}{*}{ Mean } \\
\hline & 12 hours & \begin{tabular}{|l|}
24 \\
hours
\end{tabular} & $\begin{array}{l}36 \\
\text { hours }\end{array}$ & & 12 hours & $\begin{array}{l}24 \\
\text { hours }\end{array}$ & $\begin{array}{l}36 \\
\text { hours }\end{array}$ & \\
\hline 5 & \begin{tabular}{|l|}
0.00 \\
$(0.00)$ \\
\end{tabular} & \begin{tabular}{|l|}
0.00 \\
$(0.00)$
\end{tabular} & $\begin{array}{l}0.00 \\
(0.00)\end{array}$ & $\begin{array}{l}\mathbf{0 . 0 0} \\
(\mathbf{0 . 0 0})\end{array}$ & 0.00 & 0.00 & 0.00 & 0.00 \\
\hline 10 & $\begin{array}{l}34.92 \\
(36.20)\end{array}$ & $\begin{array}{l}44.93 \\
(42.07)\end{array}$ & $\begin{array}{l}45.03 \\
(42.79)\end{array}$ & $\begin{array}{l}41.59 \\
(40.11) \\
\end{array}$ & 99.76 & 115.25 & 116.95 & 110.75 \\
\hline 15 & $\begin{array}{l}60.89 \\
(42.07)\end{array}$ & $\begin{array}{l}72.66 \\
(58.46)\end{array}$ & $\begin{array}{l}73.96 \\
(58.97)\end{array}$ & $\begin{array}{l}68.74 \\
(56.06) \\
\end{array}$ & 180.39 & 201.74 & 202.98 & 194.62 \\
\hline 20 & \begin{tabular}{|l|}
6.03 \\
$(14.19)$
\end{tabular} & \begin{tabular}{|l|}
8.85 \\
$(17.29)$
\end{tabular} & $\begin{array}{l}9.96 \\
(17.96)\end{array}$ & $\begin{array}{l}7.91 \\
(16.26)\end{array}$ & 55.36 & 68.41 & 69.51 & 64.06 \\
\hline 25 & $\begin{array}{l}0.00 \\
(0.00)\end{array}$ & $\begin{array}{l}0.00 \\
(0.00)\end{array}$ & $\begin{array}{l}0.00 \\
(0.00)\end{array}$ & $\begin{array}{l}0.00 \\
(0.00)\end{array}$ & 0.00 & 0.00 & 0.00 & 0.00 \\
\hline 30 & $\begin{array}{l}0.00 \\
(0.00)\end{array}$ & \begin{tabular}{|l|}
0.00 \\
$(0.00)$
\end{tabular} & $\begin{array}{l}0.00 \\
(0.00)\end{array}$ & $\begin{array}{l}\mathbf{0 . 0 0} \\
(\mathbf{0 . 0 0})\end{array}$ & 0.00 & 0.00 & 0.00 & 0.00 \\
\hline Mean & \begin{tabular}{|l|}
16.98 \\
$(16.95)$
\end{tabular} & \begin{tabular}{|l|}
21.07 \\
$(19.64)$
\end{tabular} & $\begin{array}{l}21.97 \\
(20.04)\end{array}$ & & 55.92 & 64.4 & 65.94 & \\
\hline $\mathrm{CD}_{0.05}$ & \multicolumn{4}{|c|}{$\begin{array}{l}\text { Temperature }(T)=0.6 \\
\text { Time }(H)=0.4 \\
\text { TxH }=01.0\end{array}$} & \multicolumn{4}{|l|}{$\begin{array}{l}T=1.02 \\
H=0.72 \\
T x H=1.8\end{array}$} \\
\hline
\end{tabular}

* Figures in the parentheses are arc sine transformed values 
Table.3 Effect of different relative humidity levels on sporangial germination and germ tube length of Peronospora destructor

\begin{tabular}{|c|c|c|c|c|c|c|c|c|}
\hline \multirow{2}{*}{$\begin{array}{l}\text { Relative } \\
\text { humidity } \\
\qquad \%)\end{array}$} & \multicolumn{3}{|c|}{$\begin{array}{c}\text { Sporangial germination } \\
(\%)\end{array}$} & \multirow[t]{2}{*}{ Mean } & \multicolumn{3}{|c|}{ Germ tube length $(\mu \mathrm{m})$} & \multirow[t]{2}{*}{ Mean } \\
\hline & 12 hours & 24 & $\begin{array}{l}36 \\
\text { hours }\end{array}$ & & \begin{tabular}{|c|}
12 \\
hours
\end{tabular} & 24 hours & $\begin{array}{l}36 \\
\text { hours }\end{array}$ & \\
\hline 100 & $\begin{array}{c}64.21 \\
(53.24)\end{array}$ & $\begin{array}{c}75 \\
(59.1)\end{array}$ & $\begin{array}{c}75.9 \\
(59.78)\end{array}$ & $\begin{array}{l}71.40 \\
(57.73)\end{array}$ & 100.06 & 140.33 & 142.63 & 126.91 \\
\hline 98.5 & $\begin{array}{c}55.91 \\
(48.38)\end{array}$ & $\begin{array}{l}65.57 \\
(54.05)\end{array}$ & \begin{tabular}{|c|}
66.24 \\
$(54.65)$
\end{tabular} & $\begin{array}{r}62.35 \\
(52.16)\end{array}$ & 77.87 & 120.11 & 122.11 & 106.03 \\
\hline 95.1 & $\begin{array}{c}24.3 \\
(29.52)\end{array}$ & $\begin{array}{l}37.53 \\
(37.76)\end{array}$ & \begin{tabular}{|l|}
38.53 \\
$(37.96)$
\end{tabular} & $\begin{array}{l}33.12 \\
(35.02)\end{array}$ & 63.33 & 85.68 & 86.68 & 78.23 \\
\hline 88.5 & $\begin{array}{c}0.00 \\
(0.00)\end{array}$ & $\begin{array}{c}0.00 \\
(0.00)\end{array}$ & \begin{tabular}{|c|}
0.00 \\
$(0.00)$
\end{tabular} & $\begin{array}{c}0.00 \\
(0.00)\end{array}$ & 0.00 & 0.00 & 0.00 & 0.00 \\
\hline$\overline{82.9}$ & $\begin{array}{c}0.00 \\
(0.00)\end{array}$ & $\begin{array}{c}0.00 \\
(0.00)\end{array}$ & \begin{tabular}{|c|}
0.00 \\
$(0.00)$ \\
\end{tabular} & $\begin{array}{c}0.00 \\
(0.00)\end{array}$ & 0.00 & 0.00 & 0.00 & 0.00 \\
\hline 75.6 & $\begin{array}{c}0.00 \\
(0.00)\end{array}$ & $\begin{array}{c}0.00 \\
(0.00)\end{array}$ & $\begin{array}{c}0.00 \\
(0.00) \\
\end{array}$ & $\begin{array}{c}\mathbf{0 . 0 0} \\
(\mathbf{0 . 0 0})\end{array}$ & 0.00 & 0.00 & 0.00 & 0.00 \\
\hline 56.8 & $\begin{array}{c}0.00 \\
(0.00)\end{array}$ & $\begin{array}{c}0.00 \\
(0.00)\end{array}$ & \begin{tabular}{|c|}
0.00 \\
$(0.00)$
\end{tabular} & $\begin{array}{c}0.00 \\
(0.00)\end{array}$ & 0.00 & 0.00 & 0.00 & 0.00 \\
\hline $\mathbf{0}$ & $\begin{array}{c}0.00 \\
(0.00)\end{array}$ & $\begin{array}{c}0.00 \\
(0.00)\end{array}$ & \begin{tabular}{|c|}
0.00 \\
$(0.00)$
\end{tabular} & $\begin{array}{c}0.00 \\
(0.00)\end{array}$ & 0.00 & 0.00 & 0.00 & 0.00 \\
\hline Mean & $\begin{array}{c}18.05 \\
(15.74)\end{array}$ & $\begin{array}{l}22.26 \\
(18.96)\end{array}$ & $\begin{array}{l}22.58 \\
(19.01)\end{array}$ & & 30.16 & 43.27 & 45.65 & \\
\hline CD0.05 & $\begin{array}{c}\text { RH } \\
(\mathrm{R})=0.39 \\
\text { Time }(\mathrm{H})= \\
0.24 \\
\mathrm{RxH}=0.68 \\
\end{array}$ & & & & $\begin{array}{c}\text { CD0.0 } \\
5\end{array}$ & $\begin{array}{c}\mathrm{RH}(\mathrm{R})=2.18 \\
\text { Time }(\mathrm{H})=1.34 \\
\mathrm{RxH}=3.78\end{array}$ & & \\
\hline
\end{tabular}

\footnotetext{
* Figures in the parentheses are arc sine transformed values
} 
Table.4 Effect of meteorological factors on the development of downy mildew on onion during 2017-18

\begin{tabular}{|c|c|c|c|c|c|c|}
\hline & & \multirow{2}{*}{$\begin{array}{c}\text { Mean } \\
\text { Maximum }\end{array}$} & \multirow{2}{*}{$\begin{array}{c}\text { Mean } \\
\text { Minimum }\end{array}$} & \multirow{2}{*}{$\begin{array}{c}\text { Cumulative } \\
\text { rainfall }\end{array}$} & \multirow{2}{*}{$\begin{array}{c}\text { Average } \\
\text { relative }\end{array}$} & \multirow{2}{*}{$\begin{array}{c}\text { Disease } \\
\text { index }\end{array}$} \\
\hline \multicolumn{2}{|c|}{ Date of Observation } & & & & & \\
\hline & & temperature & temperature & \multirow{2}{*}{$(\mathbf{m m})^{*}$} & Humidity & \multirow{2}{*}{$(\%)$} \\
\hline & & $\left({ }^{0} \mathrm{C}\right)^{*}$ & $\left({ }^{\circ} \mathbf{C}\right)^{*}$ & & $(\%)^{*}$ & \\
\hline 25 & Feb-28 Feb & 22.12 & 7.6 & 3.4 & 52.8 & 3.55 \\
\hline 01 & Mar-04 Mar & 21.45 & 8.2 & 1 & 55 & 8.67 \\
\hline 05 & Mar - 08 Mar & 22.5 & 5.6 & 3 & 47 & 16.99 \\
\hline 09 & Mar-12 Mar & 24.35 & 7.8 & 0 & 38 & 23.43 \\
\hline 13 & Mar-16 Mar & 24.2 & 6.4 & 0 & 45.75 & 33.56 \\
\hline 17 & Mar-20 Mar & 24.45 & 9.8 & 0 & 40 & 48.67 \\
\hline 21 & Mar-24 Mar & 23.27 & 8 & 3.35 & 66.12 & 51.34 \\
\hline 25 & Mar - 28 Mar & 26.5 & 8.2 & 0 & 51 & 53.66 \\
\hline 29 & Mar-1 Apr & 29.3 & 7.4 & 0 & 67 & 58.11 \\
\hline 02 & Apr-05 Apr & 28.5 & 9.4 & 0 & 68 & 58.78 \\
\hline 06 & Apr-09 Apr & 25.3 & 6.7 & 0 & 68 & 72.76 \\
\hline 10 & Apr-13Apr & 26.4 & 5.8 & 0 & 50 & 71.11 \\
\hline 14 & Apr-17Apr & 26.2 & 12.3 & 0 & 44 & 70.56 \\
\hline 18 & Apr-21Apr & 27.5 & 10.8 & 0 & 58 & 70.09 \\
\hline 22 & Apr-25Apr & 24.3 & 13.2 & 0 & 59 & 69.56 \\
\hline \multicolumn{2}{|c|}{ 26Apr-29Apr } & 25.4 & 16.5 & 1 & 67.5 & 68.22 \\
\hline 30 & Apr-3 May & 23.2 & 18.2 & 3.5 & 65 & 68.84 \\
\hline \multicolumn{2}{|c|}{4 May-7May } & 24.5 & 16.3 & 1.5 & 51 & 67.21 \\
\hline 08 & May-11May & 25.2 & 15.7 & 2 & 53 & 67.02 \\
\hline 12 & May-15 May & 26.6 & 17.23 & 2.2 & 48 & 66.65 \\
\hline
\end{tabular}

Table.5 Simple correlation coefficients between per cent disease index (PDI) and meteorological factors

\begin{tabular}{|l|l|}
\hline Meteorological factors & Year 2018 \\
\hline Maximum temperature $\left({ }^{\circ} \mathrm{C}\right) \mathrm{x}$ PDI & $0.774^{* *}$ \\
\hline Minimum temperature $\left({ }^{\circ} \mathrm{C}\right) \mathrm{x}$ PDI & $0.620 *$ \\
\hline Cumulative rainfall $(\mathrm{mm}) \mathrm{x}$ PDI & -0.178 \\
\hline $\begin{array}{l}\text { Average Relative humidity }(\%) \mathrm{x} \\
\text { PDI }\end{array}$ & 0.353 \\
\hline
\end{tabular}

** - significant at $1 \%$ level

* - significant at $5 \%$ level 
Table.6 Partial correlation coefficients between per cent disease index (PDI) and meteorological factors

\begin{tabular}{|l|l|}
\hline Meteorological factors & $\mathbf{2 0 1 8}$ \\
\hline Maximum temperature $\left({ }^{\mathrm{O}} \mathrm{C}\right) \times \mathrm{PDI}$ & $0.586 * *$ \\
\hline Minimum temperature $\left({ }^{\mathrm{O}} \mathrm{C}\right) \times \mathrm{PDI}$ & 0.547 \\
\hline Rainfall (mm) x PDI & -0.132 \\
\hline Relative humidity $(\%)$ x PDI & 0.238 \\
\hline $\begin{array}{r}* * \text { - significant at 1 \% level } \\
* \text { - significant at 5\% level }\end{array}$ \\
\hline
\end{tabular}

Table.7 Multiple Regressions

\begin{tabular}{l|l|l|}
\hline Year & Regression equation & $\mathbf{R}^{\mathbf{2}}$ \\
\hline $\mathbf{2 0 1 8}$ & $\mathrm{Y}=-125.687+5.39 \mathrm{X}_{1}{ }^{* *}+2.17 \mathrm{X}_{2}{ }^{*}-1.51 \mathrm{X}_{3}+0.33 \mathrm{X}_{4}$ & 0.874 \\
\hline$* *$ - significant at $0.01 \% ; \quad{ }_{\text {- significant at } 0.05 \%}$ \\
$\begin{array}{l}\text { Where, } \mathrm{Y}=\text { Disease index }(\%) ; \mathrm{X}_{1}=\text { Maximum temperature }\left({ }^{\circ} \mathrm{C}\right) ; \mathrm{X}_{2}=\text { Minimum temperature }\left({ }^{\circ} \mathrm{C}\right) ; \\
\mathrm{X}_{3}=\text { Rainfall }(\mathrm{mm}) \text { and } \mathrm{X}_{4}=\text { Average relative humidity }(\%)\end{array}$
\end{tabular}

\section{Correlation and regression analysis}

Simple, partial and multiple correlations were worked out between per cent disease index (PDI) and meteorological factors (mean maximum temperature, mean minimum temperature, cumulative rainfall and average relative humidity) for the cropping season 2017-2018. Data on simple and partial correlation coefficient indicated the role of mean temperature (maximum, minimum) and average relative humidity and found them positively correlated with the disease development but the cumulative rainfall did not showed any impact and hence was negatively correlated with the progress of the disease. Simple correlation coefficient between the onion downy mildew and mean temperature maximum was positive and highly significant. Similarly mean temperature minimum and average relative humidity were positive and highly significant while cumulative rainfall developed negative correlation and did not found significant. Similar results were observed in case of partial correlation coefficient calculation. Gupta and Paul (2001) concluded that the downy mildew pathogen require cool temperature $\left(22^{\circ} \mathrm{C}\right)$ and relative humidity greater than 97 per cent with cloudy days additionally supporting the development of the disease and found them positively correlated.

\section{Multiple regressions}

The multiple coefficient of determination $\left(\mathrm{R}^{2}\right)$ was calculated to measure the contribution of linear function of independent variables, such as mean maximum temperature (Tmax), mean minimum temperature (Tmin), cumulative rainfall (Rf) and average relative humidity (RH) on dependent variable i.e. PDI and is presented in Table 7.

Multiple correlation coefficients, as depicted in Table 4.7 between the onion downy mildew (PDI) and other meteorological factors indicated that 87.40 per cent disease index was caused by mean maximum temperature, mean minimum temperature, average relative humidity and cumulative rainfall collectively. While the rest of the variations might have contributed the change 
or variation due to unexplained variables (error variation) and or the factors not included in the present investigations.

The present investigation on onion downy mildew (Peronospora destructor (Berk.) Casp. ex Berk) were undertaken with respect to occurrence, identification, pathogenecity and epidemiological studies.

Onion downy mildew was low, moderately and severely prevalent in all onion growing areas of Solan district. Maximum disease incidence $(39.24 \%)$ and severity $(58.65 \%)$ of downy mildew of onion was observed at Pandah and followed by Khaltoo during the cropping season of 2017-2018 and mean per cent incidence and disease severity of downy mildew were recorded to be 23.71 and 25.34, respectively at all other locations surveyed of Solan district.

Characteristic symptoms seen on leaves were initially circular or elliptical lesions that later becomes white, slightly sunken and roughened and get covered with the grey downy masses that turned purplish after heavy rain. In case of severe downy mildew infestation, necrosis followed by girdling was also seen. Few bottleneck bulbs were seen due to severe infection of aerial portions of the plant.

On the basis of appearance and morphological characteristics of the pathogen like nature of mycelium which observed as hyaline, aseptate with a width of 3.6-6.9 $\mu \mathrm{m}$ and characteristic dichotomously branched sporangiophores bearing pyriform sporangia measuring 50.4$65.8 \times 24.6-25.2 \mu \mathrm{m}$ in size. Based on the morphological characters, the pathogen was identified as Peronospora destructor (Berk.) Casp. ex Berk.

To prove the pathogenicity, the pathogen was inoculated by following detached leaf with sporangial suspension and typical symptoms similar to the original, developed after 8 days. Epidemiological studies of pathogen revealed that pathogen preferred a temperature of $15^{\circ} \mathrm{C}$ as optimum for sporangial germination and the favourable relative humidity was above 95.1 per cent with maximum sporangial germination at 100 per cent. Disease initiated when favourable conditions like temperature and relative humidity prevailed for at least two days.

Under field conditions disease appeared at the end of February 2018, due to the presence of favourable mean maximum temperature $\left(22.12{ }^{\circ} \mathrm{C}\right)$, mean minimum temperature $(7.6$ ${ }^{\circ} \mathrm{C}$ ) and average relative humidity (52.8\%) and attained maximum severity $(72.76 \%)$ during second week of April, 2018. The simple and partial correlation were highly significant and positively correlated with mean maximum temperature, mean minimum temperature, average relative humidity and negative with rainfall.

Multiple correlation analysis has shown that 87.4 per cent disease severity was due to the cumulative effect of all the factors considered under the study. From the above discussion it is concluded that downy mildew of onion is a serious disease in low lying areas of Solan district of Himachal Pradesh and caused by an oomycetes Peronospora destructor (Berk.) Casp. ex Berk. The congenial temperature was found to be $15^{\circ} \mathrm{C}$ and relative humidity more than 95 per cent for its development.

\section{References}

Brewster JL. 2001. The structure of edible alliums. In: Onions and other allium (López $\mathrm{M}$ and Brewster JL eds). Editorial Acribia, Zaragoza. pp.230266.

Cohen Y, Moshe V and Brigitte M. 2016. 
BABA-induced resistance: milestones along a 55-year journey. Phytoparasitica 44:513-18.

Develash RK and Sugha SK. 1997. Management of downy mildew (Peronospora destructor) of onion (Allium cepa). Crop Protection 16: 6367.

Domingues RJ and Töfoli JG. Onion mildew: Importance, identification and control methods. Technical Disclosure 71. Biological Institute, São Paulo. 31p.

Gianessi LP and Reigner N. 2005. The value of fungicides in US crop production. Crop Life Foundation, Crop Protection Research Institute, Washington, DC. $243 p$.

Gilles T, Phelps K, Clarkson JP and Kennedy R. 2004. Development of MILIONCAST, an improved model for predicting downy mildew sporulation on onions. Plant Disease 88: 695-702.

Göker M, Voglmayr H, Riethmüller A and Oberwinkler F. 2007. How do obligate parasites evolve? A multi-gene phylogenetic analysis of downy mildews. Fungal Genetics and Biology 44:105-122.

Gomez KA and Gomez AA. 1984. Statistical Procedures for Agricultural Research. $2^{\text {nd }}$ ed.

Gupta VK and Paul YS. 2001. Diseases of Vegetable Crops. Kalyani Publisher, New Dehli. 223p.

Jayakumar M, Ponnuswamy $\mathrm{K}$ and Amanullah MM. 2008. Influence of nitrogen and intercropping on pest incidence, yield arributes and yield of cotton. Journal of applied scientific research 4: 224-28.

John Wiley and Sons Inc, New York. 680p.

Kennedy R. 1998. Bulb onions: Evaluation of fungicides for control of downy mildew (Peronospora destructor). Horticultural Development Council, Annual Report (Year 1) for project, FV.10 p.
Kofoet A, Kik C, Wietsma WA, de Vries JN. 1990. Inheritance of resistance to downy mildew (Peronospora destructor [Berk.] Casp.) from Allium roylei Stearn. in the backcross Allium cepa L. $\mathrm{x}$ (A. roylei x A. cepa). Plant Breeding 105:144-149.

Langston DB, and Sumner DR. 2000. First report of downy mildew (caused by Peronospora destructor) of onion in Georgia. Plant Disease 84:489-91.

McKinney HH. 1923. Influence of soil temperature and moisture on infection of wheat seedling by Helminthosporium sativum. Journal of Agricultural Research 26:195-217.

Mohibullah.1991. Studies on Major Diseases of Bulb Vegetables (onion and garlic) in N.F.W.P. Province, Pakistan: Final Technical Report (October 1986 to September 1991). Agricultural Research Institute, Tarnab (Peshawar), N.W.P. Pakistan.55p.

Murphy P and Mckay R. 1926. The downy mildew of onions (Peronospora schleideni) with particular reference to the hibernation of the parasite. The Scientific Proceedings of the Royal Dublin Society 18:237-61.

Palti J.1989. Epidemiology, prediction and control of onion downy mildew caused by Peronospora destructor. Phytoparasitica 17:31-48.

Premila A and Sophiarani Y. 2015. Downy Mildew of Onion: Epidemiological Aspects. International Journal of Innovative Research and Development 4:13-15.

Premila A. 2013. Fungal airspora over onion field in Manipur valley. International Journal of Current Science \&Technology 2: 177 - 79.

Ross IA. 2001. Medicinal Plants of the world: Chemical Constituents, Traditional and Modern Medicinal Uses. Vol 2. Humana Press, Totowa. 487p. 
Schwartz and Mohan, 2008; Schwartz HF and Mohan SK. 1995. Compendium of Onion and Garlic Diseases. American Phytopathological Society, St. Paul, MN.70p.

Song RG, Lu WP, Li CY, Wang $\mathrm{J}$ and ShenYJ. 1998. Inheritance of resistance to Plasmopara viticola in intraspecific cross of Vitis amurensis Rupr. Acta Horticulturae 25: 117-122.

Stevens (1916). Stevens NE. 1916. A method of studying the humidity relation of fungi in culture. Phytopathology 6: 428-
32.

Surviliené E, Valiskaité A and Raudonis L. 2008. The effect of fungicides on the development of downy mildew of onions. Zemdirbyste Agriculture 95: 171-179.

Viranyi F. 1975.Studies on the biology and ecology of onion downy mildew (Peronospora destructor) Berk. (Fries) in Hungary. Epidemiology of the disease. Acta Phytopathologica Academiae Scientiarum Hungaricae 10:321-28.

\section{How to cite this article:}

Ankita, Sunita Chandel, Rajender Sharma and Vijay Kamal Meena. 2020. Epidemiological Studies of Downy Mildew of Onion. Int.J.Curr.Microbiol.App.Sci. 9(05): 01-12.

doi: https://doi.org/10.20546/ijcmas.2020.905.001 